\title{
Perbandingan Pendapatan Usahatani Cabai Rawit dengan Menggunakan Pupuk Anorganik dan Pupuk Campuran(Organik, dan Anorganik) (Studi Kasus di Subak Kudungan, Desa Bontihing, Kecamatan Kubutambahan, Kabupaten Buleleng)
}

\author{
RIFKI ARDIAN, WAYAN SUDARTA, I KETUT RANTAU
}

Program Studi Agribisnis, Program Non Reguler, Fakultas Pertanian, Universitas Udayana. Jl. PB Sudirman Dps 80232

Email: rifkiardian31@gmail.com sudarta_wayan@ymail.com

\section{Abstract \\ The Comparison of Hot Chili Farming Incomes by Using Organic Fertilizer and Mixture Fertilizer (Organic, and Inorganic) \\ (Case Study In Subak Kudungan, Bontihing Village, Kubutambahan Distric, Buleleng Regency)}

The problem faced by famers of hot chili is obstacle the cultivation which done from the less production result of achieve national potential target of 10 to 20 tonnes/ha and to overcome obstacles especially in plants cultivation which done by applying a low-tech chemical inputs and cultivation technology of conservation which is implemented in integrated crop processing hot chili by applying organic fertilizer. Therefore this research aims to know the comparison of hot chili farming incomes by using organic fertilizer and mixture fertilizer. This research was conducted from August until September 2016 in Subak Kudungan Bontihing village Kubutambahan distric Buleleng regency. The data were analyzed by income analysis, $\mathrm{R} / \mathrm{C}$ ratio analysis and Uji-t analysis. The results showed that hot chili farming incomes in one season per hectare using inorganic fertilizer is loweer than using a mixture fertilizer, use inorganic fertilizer $\mathrm{Rp} 21.586 .846,00$ and use mixture fertilizer $\mathrm{Rp} 26.489 .791,00$. $\mathrm{R} / \mathrm{C}$ ratio hot chili farming using organic fertilizer which is 2,09 higher than using mixture fertilizer 2,03. The result of Uji-t analysis showed hot chili farming incomes using inorganic fertilizer and mixture fertilizer was not significantly different at the level $5 \%$.

Keywords: incomes, hot chili farming, inorganic fertilizer, mixture fertilizer, subak

\section{Pendahuluan}

\subsection{Latar Belakang}

Sektor pertanian memiliki kedudukan yang sangat berpengaruh terahadap pertumbuhan perekonomian di Indonesia, mengingat Indonesia merupakan daerah yang sangat potensial dalam pengembangan pertanian. Peningkatan sektor pertanian 
merupakan target utama dalam meningkatkan pertumbuhan perekonomian di Indonesia. Akan tetapi dalam meningkatkan pendapatan dan kesejahteraan petani, seringkali dihadapkan pada permasalahan pengetahuan petani yang masih relatif rendah, keterbatasan modal, minimnya inovasi yang diberikan kepada petani, serta kurangnya keterampilan petani yang nantinya akan berpengaruh pada penerimaan (Antara, dkk, 2006).

Sektor pertanian yang sangat potensial untuk dikembangkan di Indonesia adalah sektor pertanian hortikultura, salah satu komoditi hortikultura yang sangat dibutuhkan oleh hampir semua orang dari berbagai lapisan masyarakat adalah cabai rawit (Rostini, 2011). Tanaman cabai rawit (Capsicum frutescens L.) merupakan salah satu dari beberapa tanaman hortikultura yang potensial untuk dikembangkan (Cahyono, 2003).

Produksi cabai rawit di Indonesia dalam lima tahun terakhir (2010 s.d 2014) menunjukkan peningkatan dengan pertumbuhan sekitar 8,36\% (BPS, 2015). Peningkatan produksi cabai rawit berdasarkan data pada tahun 2010 s.d 2014 tetap tidak dapat memenuhi kebutuhan cabai rawit nasional sehingga impor cabai rawit terus dilakukan setiap tahunnya, hal ini dikarenakan belum tercapainya potensi terhadap produksi cabai rawit sebesar 10 s.d 20 ton/ha (Ditjen Bina Produksi Hortikultura, 2015).

Upaya yang dapat dilakukan untuk mengatasi beberapa kendala terutama pada budidaya tanaman dilakukan dengan menerapkan teknologi budidaya rendah input kimia dan teknologi budidaya konservasi yang diimplementasikan pada Pengelolaan Tanaman Terpadu (PTT) cabai rawit. Pengelolaan Tanaman Terpadu merupakan suatu pendekatan budidaya tanaman yang berdasarkan pada keseimbangan ekonomi dan ekologi, dengan tujuan utamanya adalah meraih keseimbangan antara pengeluaran dan pendapatan, antara proses alami dan teknologi, dengan selalu mengingat keberlanjutan dari usahatani tersebut (Setiawati, 2010).

Bali memiliki kondisi tanah yang sangat potensial untuk penanaman sayur mayur. Produksi sayur mayur di Bali dari tahun 2010 s.d 2014 sangat baik, dimana produksi sayur mayur tahun 2014 sebesar 221.620 ton. Sayur mayur yang paling banyak diproduksi adalah jenis kubis sebesar 42.794 ton $(19,30 \%)$ dan cabai rawit sebesar 28.440 ton (12,83\%) (BPS, 2015). Sentra produksi cabai rawit di Bali berada di Kabupaten Karangasem, tetapi dengan berkembangnya peningkatan produktivitas di Kabupaten Buleleng tidak menutup kemungkinan Kabupaten Buleleng akan menjadi sentra produksi cabai rawit di Bali. Perkembangan usahatani cabai rawit di Kabupaten Buleleng tidak luput dari kontribusi daerah pendukung produksi cabai rawit, adapun daerah pendukung kontribusi di Kabupaten Buleleng berada di Kecamatan Kubutambahan, salah satu subak yang sangat menerima teknologi/inovasi baru untuk usahatani cabai rawit yaitu di Desa Bontihing, Subak Kudungan.

Subak Kudungan, Desa Bontihing, Kecamatan Kubutambahan sementara ini mendapat program pemerintah yang bertujuan untuk menekan penggunaan pupuk 
anorganik dengan menambah pupuk organik sebagai campuran. Berdasarkan observasi di lapangan bahwa keseluruhan kegiatan pertanian yang dilakukan antara petani cabai rawit dengan mengunakan pupuk anorganik dan petani cabai rawit menggunakan pupuk campuran hampir sama, perbedaan hanya terletak pada aktivitas pengolahan lahan. Petani cabai rawit yang menggunakan pupuk campuran menambah pupuk organik pada saat pengolahan lahan, sedangkan petani cabai rawit yang menggunakan pupuk anorganik hanya mengolah lahan.

Adanya perbedaan dari aktivitas pemupukan, biaya penambahan pupuk dan tenaga kerja yang digunakan antara petani yang telah menggunakan pupuk organik dan tanpa menggunakan pupuk organik, tentunya akan menghasilkan produksi dan biaya yang berbeda. Fenomena inilah yang mendorong penulis untuk melakukan penelitian mengenai "Perbandingan Pendapatan Usahatani Cabai Rawit dengan Menggunakan Pupuk Anorganik dan Pupuk Campuran (Organik, Anorganik)" studi kasus di Subak Kudungan, Desa Bontihing, Kecamatan Kubutambahan, Kabupaten Buleleng.

\subsection{Tujuan Penelitian}

Penelitian ini bertujuan untuk mengetahui perbandingan pendapatan bersih usahatani cabai rawit dengan menggunakan pupuk anorganik dan pupuk campuran (organik dan anorganik) di Subak Kudungan, Desa Bontihing, Kecamatan Kubutambahan, Kabupaten Buleleng.

\section{Metode Penelitian}

\subsection{Lokasi dan Waktu Penelitian}

Penelitian ini dilakukan di Subak Kudungan, Desa Bontihing, Kecamatan Kubutambahan, Kabupaten Buleleng. Pemilihan lokasi penelitian dilakukan secara purposive sampling, yaitu penentuan lokasi secara sengaja dengan dasar pertimbangan tertentu. Pengumpulan data dilakukan pada bulan Agustus sampai dengan September 2016 yang melibatkan petani cabai rawit yang menggunakan pupuk anorganik dan menggunakan pupuk campuran.

\subsection{Penentuan Populasi dan Responden}

Populasi merupakan kumpulan individu atau objek penelitian yang memiliki ciri-ciri yang telah ditetapkan. Berdasarkan ciri-ciri tersebut, populasi dapat dipahami sebagai kelompok unit analisis atau objek pengamatan yang minimal memiliki satu persamaan karakteristik. Responden adalah bagian dari populasi yang memiliki karakteristik yang relatif sama dan dianggap bisa mewakili populasi (Hakim, 2004). Ruang lingkup populasi yang dilakukan dalam penelitian ini adalah seluruh petani aktif, yang membudidayakan tanaman cabai rawit dan tergabung dalam anggota Subak Kudungan, yaitu sebanyak 34 orang, yang terdiri atas 18 orang menggunakan pupuk anorganik dan 16 orang yang menggunakan pupuk campuran dengan dosis yang tepat. Pengambilan responden dilakukan secara sensus yaitu semua petani yang 
menggunakan pupuk campuran sebanyak 16 orang dan petani yang menggunakan pupuk anorganik sebanyak 16 orang.

\subsection{Metode Pengumpulan Data, Variabel Penelitian dan Analisis Data}

Metode pengumpulan data yang digunakan dalam penelitian ini adalah pengamatan (observasi), wawancara, dan metode kepustakaan. Variabel penelitian adalah kondisi-kondisi yang oleh peneliti dimanipulasikan, dikontrol atau diobservasi dalam suatu penelitian (Antara, 2006). Variabel dalam penelitian ini adalah pendapatan bersih usahatani, diukur dengan skala pengukuran ratio. Analisis data yang digunakan dalam penelitian ini adalah analisis pendapatan, analisis $\mathrm{R} / \mathrm{C}$ ratio, analisis Uji T dan analisis deskriptif.

\section{Hasil dan Pembahasan}

\subsection{Karakteristik Responden}

Karakteristik responden yang dibahas dalam penelitian ini meliputi:

1. Umur merupakan lamanya responden hidup di dunia ini hingga dilakukannya penelitian ini. Adapun rata-rata umur responden dengan menggunakan pupuk anorganik 54 tahun, dan responden dengan menggunakan pupuk campuran 49 tahun, dengan begitu rata-rata umur responden kedua kelompok petani dalam penelitian ini sama-sama memiliki umur produktif yang kurang dari 64 tahun.

2. Pendidikan, merupakan hal yang penting, tingkat pendidikan adalah salah satu faktor yang menentukan tingkat kemampuan seseorang dalam menyerap pengetahuan. Tingginya tingkat pendidikan juga mencerminkan kemampuan seseorang menerima suatu inovasi, karena umumnya orang yang berpendidikan tinggi akan lebih terbuka wawasannya untuk sebuah perubahan (Okas, 2015). Tingkat pendidikan responden cabai rawit di Subak Kudungan yang terbagi dalam dua kelompok terlihat bahwa tingkat pendidikan dari masing-masing kelompok memiliki rata-rata pendidikan tamatan SD dengan 14 orang atau sebesar $(87,5 \%)$ responden dengan menggunakan pupuk anorganik dan delapan orang atau sebesar (50\%) responden yang menggunakan pupuk campuran, sedangkan hanya sebagian kecil responden yang mengenyam tingkat pendidikan tamatan (SMP, SMA, dan Perguruan Tinggi).

3. Penguasaan lahan, merupakan keseluruhan luas lahan yang sedang digarap baik yang dimiliki sendiri, menyewa, maupun menyakap (Okas, 2014). Total luas garapan responden usahatani cabai rawit dengan menggunakan pupuk anorganik seluas 4,39 ha, sedangkan total luas lahan usahatani cabai rawit dengan menggunakan pupuk campuran seluas 3,88 ha dan lahan yang diusahakan sebagian memiliki status milik sendiri dan menyekap. Rata-rata luas lahan garapan yang dikelola oleh petani responden usahatani cabai rawit dengan menggunakan pupuk anorganik dan pupuk campuran di Subak Kudungan sebesar 0,2744 ha atau sama dengan (27,44 are) untuk responden yang 
menggunakan pupuk anorganik dan 0,2425 ha atau sama dengan $(24,25$ are) responden yang menggunakan pupuk campuran.

4. Pekerjaan, dibedakan menjadi dua yaitu pekerjaan pokok dan pekerjaan sampingan. Berdasarkan hasil penelitian dari 32 responden, yang terbagi menjadi dua kelompok, seluruh responden memiliki pekerjaan pokok sebagai petani. Responden juga mempunyai pekerjaan sampingan, dari 32 responden usahatani cabai rawit terdapat 26 responden yang memiliki pekerjaan sampingan atau sekitar $(81,25 \%)$ dan enam responden tidak memiliki pekerjaan sampingan sekitar $(18,75 \%)$.

\subsection{Pendapatan Usahatani Cabai Rawit dengan Menggunakan Pupuk Anorganik dan Pupuk Campuran}

\section{Biaya usahatani}

Biaya usahatani dalam penelitian ini mencangkup biaya tetap ( $f$ ix cost), biaya variabel (variable cost) dan biaya total (total cost). Total biaya usahatani cabai rawit dengan menggunakan pupuk anorganik dalam satu siklus musim tanam per luas lahan garapan di Subak Kudungan sebesar Rp 5.525.515,00 yang terdiri dari biaya tetap sebesar Rp 297.741,00 (5,39\%) yang meliputi biaya penyusutan, pajak tanah, alat pertanian, iuran subak dan biaya upacara ritual per musim tanam, biaya terbesar yang dikeluarkan adalah biaya penyusutan alat pertanian sebesar Rp 152.011,00 $(2,75 \%)$ dari total biaya usahatani cabai rawit menggunakan pupuk anorganik. Biaya tidak tetap usahatani cabai rawit menggunakan pupuk anorganik yang dikeluarkan sebesar Rp 5.227.774,00 (94,61\%), meliputi biaya benih, pupuk, kapur, pestisida, mulsa dan tenaga kerja, biaya terbesar yang dikeluarkan pada biaya tidak tetap adalah biaya tenaga kerja yang mencapai Rp 3.626.836,00 (65,64\%) dari total biaya usahatani cabai rawit dengan menggunakan pupuk anorganik.

Adapun total biaya usahatani cabai rawit dengan menggunakan pupuk campuran dalam satu siklus musim tanam per luas garapan di Subak Kudungan sebesar Rp 6.333.373,00 yang terdiri dari biaya tetap sebesar Rp 285.419,00 (4,51\%) meliputi biaya penyusutan, pajak tanah, alat pertanian, iuran subak, dan biaya upacara ritual per musim tanam. Biaya terbesar yang dikeluarkan dalam biaya tetap adalah biaya penyusutan alat pertanian, sebesar Rp 145.002,00 (2,40\%) dari total biaya usahatani cabai rawit dengan menggunakan pupuk campuran. Biaya tidak tetap yang dikeluarkan petani responden dengan menggunakan pupuk campuran sebesar Rp 6.047.954,00 (95,49\%) yang meliputi biaya benih, pupuk, kapur, pestisida, mulsa, dan tenaga kerja. Biaya terbesar yang dikeluarkan pada biaya tidak tetap adalah biaya tenaga kerja sebesar Rp 3.559.453,00 (56,20\%) dari total biaya usahatani cabai rawit dengan menggunakan pupuk campuran.

\section{Penerimaan dan pendapatan usahatani}

Penerimaan usahatani adalah perkalian antara produksi yang diperoleh dengan harga jual (Rahim dan Diah, 2008). Adapun penerimaan usahatani dalam penelitian ini mencangkup total produksi cabai rawit baik itu yang dikonsumsi, dijual, ataupun 
dipakai untuk pembenihan dan lain sebagainya, yang dikalikan dengan harga jual cabai rawit pada saat panen. Pendapatan usahatani adalah total pendapatan bersih yang diperoleh dari seluruh aktivitas usahatani yang merupakan selisih antara total penerimaan dengan total biaya yang dikeluarkan (Hadisapoetra,1979). Mengenai harga jual cabai rawit pada saat panen sangat bervariasi dikarenakan fluktuasi harga dalam satu musim tanam, oleh sebab itu dalam penelitian ini harga jual cabai rawit yang digunakan adalah rata-rata dari harga jual pada satu musim tanam dan diperoleh harga cabai rawit per/kg sebesar Rp 14.200,00.

Berdasarkan perhitungan dari hasil penelitian yang didapat dari produksi cabai rawit dalam satu musim tanam rata-rata responden petani cabai rawit dengan menggunakan pupuk anorganik di Subak Kudungan sebesar 793,64 kg. Adapun besarnya pendapatan bersih usahatani cabai rawit dengan menggunakan pupuk anorganik sebesar Rp 5.744.173,00 jumlah tersebut diperoleh dari selisih penerimaan usahatani Rp 11.269.688,00 dengan total biaya usahatani Rp 5.525.515,00. Data selengkapnya dituangkan pada tabel 1 .

Tabel 1.

Rata-rata Pendapatan per Musim Tanam*) Usahatani Cabai Rawit dengan Menggunakan Pupuk Anorganik dan Pupuk Campuran di Subak Kudungan Tahun 2016

\begin{tabular}{|c|c|c|c|c|c|}
\hline \multirow{2}{*}{ No } & \multirow{2}{*}{ Uraian } & \multicolumn{2}{|c|}{ Pupuk Anorganik } & \multicolumn{2}{|c|}{ Pupuk Campuran } \\
\hline & & LLG $(27,44)$ & Hektar & LLG $(24,25)$ & Hektar \\
\hline 1 & Produksi $(\mathrm{kg})$ & 793,64 & $2.892,54$ & 834,22 & $3.440,06$ \\
\hline \multirow[t]{2}{*}{2} & Harga (Rp) & 14.200 & 14.200 & 15.167 & 15.167 \\
\hline & Penerimaan (Rp) & 11.269 .688 & 41.373.778 & 12.652 .615 & 52.258 .853 \\
\hline 1 & Total biaya tetap (Rp) & 297.741 & 820.692 & 285.419 & 797.949 \\
\hline \multirow[t]{2}{*}{2} & Total biaya variabel (Rp) & 5.227 .774 & 18.999 .573 & 6.047 .954 & 25.004 .446 \\
\hline & Total biaya (Rp) & 5.525.515 & 19.820 .265 & 6.333 .373 & 25.802 .395 \\
\hline \multicolumn{2}{|c|}{ Pendapatan Bersih Usahatani (Rp) } & 5.744 .173 & 21.553 .513 & 6.319.242 & 26.456 .458 \\
\hline \multicolumn{2}{|c|}{$R / C$ ratio } & 2,04 & 2,09 & 2,00 & 2,03 \\
\hline
\end{tabular}

*) Musim tanam delapan bulan

Adapun rata-rata produksi cabai rawit yang dihasilkan pada satu siklus musim tanam per luas garapan dengan menggunakan pupuk campuran sebesar 834,22 kg. Harga jual cabai rawit dengan menggunakan pupuk campuran dilihat dari tabel 1 , pada satu siklus musim tanam sebesar Rp 15.167,00 harga tersebut didapat dari ratarata dalam satu musim tanam. Berdasarkan data pada tabel 1, pendapatan usahatani yang didapat sebesar $\mathrm{Rp}$ 6.319.242,00 angka tersebut diperoleh dari selisih penerimaan usahatani Rp 12.652.615,00 dengan total biaya usahatani Rp 6.333.373,00. 


\subsection{Perbandingan Pendapatan Usahatani Cabai Rawit dengan Menggunakan Pupuk Anorganik dan Pupuk Campuran di Subak Kudungan}

Analisis usahatani yang dilakukan dalam penelitian ini adalah membandingkan rata-rata pendapatan usahatani cabai rawit dengan menggunakan pupuk anorganik dan pupuk campuran secara rill, serta dilakukan perbandingan berdasarkan $\mathrm{R} / \mathrm{C}$ ratio dan menganalisis tingkat perbedaan dengan Uji-t yang menggunakan program SPSS 17.

\section{Perbandingan pendapatan usahatani}

Rata-rata pendapatan usahatani dalam satu musim per hektar yang diterima oleh responden cabai rawit dengan menggunakan pupuk anorganik dan dengan menggunakan pupuk campuran memiliki selisih tingkat perbedaan sebesar (Rp 4.902.945,00) dimana pendapatan usahatani responden yang menggunakan pupuk anorganik sebesar $\mathrm{Rp}$ 21.553.513,00 sedangkan pendapatan usahatani responden yang menggunakan pupuk campuran sebesar Rp 26.456.458,00. Data perbandingan rata-rata pendapatan usahatani cabai rawit dengan menggunakan pupuk anorganik dan pupuk campuran disajikan pada tabel 2.

Tabel 2.

Perbandingan Rata-rata per Hektar per Musim Tanam*) Pendapatan Usahatani Cabai Rawit dengan Menggunakan Pupuk Anorganik dan Menggunakan Pupuk Campuran di Subak Kudungan Tahun 2016

\begin{tabular}{|c|c|c|c|}
\hline \multirow[b]{2}{*}{ No } & \multirow[b]{2}{*}{ Uraian } & \multicolumn{2}{|c|}{ Usahatani Cabai Rawit } \\
\hline & & $\begin{array}{l}\text { Menggunakan Pupuk } \\
\text { Anorgnaik }\end{array}$ & $\begin{array}{l}\text { Menggunakan Pupuk } \\
\text { Campuran }\end{array}$ \\
\hline 1 & Produksi (Kg) & $2.892,54$ & $3.440,06$ \\
\hline \multirow[t]{2}{*}{2} & Harga (Rp) & 14.200 & 15.167 \\
\hline & Penerimaan (Rp) & 41.373 .778 & 52.258 .853 \\
\hline 1 & Total biaya tetap (Rp) & 820.692 & 797.949 \\
\hline \multirow[t]{2}{*}{2} & Total biaya variabel $(\mathrm{Rp})$ & 18.999 .573 & 25.004 .446 \\
\hline & Total biaya (Rp) & 19.820 .265 & 25.802 .395 \\
\hline \multicolumn{2}{|c|}{ Pendapatan usahatani (Rp) } & 21.553 .513 & 26.456 .458 \\
\hline \multicolumn{2}{|c|}{$\mathrm{R} / \mathrm{C}$ ratio } & 2,09 & 2,03 \\
\hline \multicolumn{2}{|c|}{ Uji T } & \multicolumn{2}{|c|}{$\begin{array}{c}\text { F-hitung }=0,499 \\
\text { Signifikansi }=0,485 \\
\text { t-hitung }=1,331 \\
\text { derajat bebas }(\mathrm{df})=30 \\
\text { t-tabel }(\alpha 1 \%)=2,457 \\
\text { t-tabel }(\alpha 5 \%)=1,697 \\
\text { t-tabel }(\alpha 10 \%)=1,310\end{array}$} \\
\hline
\end{tabular}

*) Musim tanam delapan bulan

\section{Perbandingan $\mathrm{R} / \mathrm{C}$ ratio}

$\mathrm{R} / \mathrm{C}$ ratio adalah singkatan dari Return Cost Ratio. Analisis R/C Ratio digunakan untuk membandingkan antara penerimaan dan biaya (Soekartawi, 1986). $\mathrm{R} / \mathrm{C}$ ratio dalam penelitian ini menunjukan usahatani cabai rawit dengan 
menggunakan pupuk anorganik dalam satu musim tanam per hektar sebesar 2,09 dengan begitu dapat diartikan bahwa setiap pemberian modal investasi sebesar Rp 1.000,00 akan memberikan penerimaan sebesar Rp 2.090,00 sedangkan R/C ratio usahatani cabai rawit dengan menggunakan pupuk campuran dalam satu musim tanam per hektar sebesar 2,03 dapat diartikan bahwa setiap pemberian modal investasi sebesar Rp 1.000,00 akan memberikan penerimaan sebesar Rp 2.030,00. Berdasarkan penjelasan secara umum hasil $\mathrm{R} / \mathrm{C}$ ratio pada usahatani cabai rawit dengan menggunakan pupuk anorganik dan pupuk campuran di Subak Kudungan dapat dikatakan menguntungkan atau layak untuk diusahakan karena hasil $\mathrm{R} / \mathrm{C}$ ratio kedua kelompok lebih dari satu $(\mathrm{R} / \mathrm{C}>1)$.

\section{3. $\quad$ Analisis $U$ Ji T}

Berdasarkan tabel 3, hasil analisis uji beda rata-rata diperoleh nilai t-hitung sebesar 1,331 < 1,697 dengan begitu t-hitung tidak lebih besar dari t-tabel $\alpha 5 \%$. Penjelasan t-tabel $\alpha 5 \%$ sebesar 1,697 didapat dari nilai df = 30 dengan tingkat kesalahan sebesar 0,05 ( $\alpha$ 5\%). Hipotesis yang diperoleh dari uji beda rata-rata nilai t-hitung dan t-tabel adalah $\mathrm{H}_{0}$ diterima dan $\mathrm{H}_{1}$ ditolak, yang artinya secara uji statistik rata-rata pendapatan usahatani cabai rawit dengan menggunakan pupuk anorganik dan pupuk campuran dalam satu musim tanam per hektar tidak berbeda nyata pada taraf $\alpha 5 \%$.

\section{Simpulan dan Saran}

\subsection{Simpulan}

Berdasarkan pokok permasalahan dan hasil analisis pada bab sebelumnya, maka dapat ditarik suatu kesimpulan dari hasil penelitian yang telah dilakukan sebagai berikut: pendapatan bersih usahatani cabai rawit dengan menggunakan pupuk anorganik dan pupuk campuran di Subak Kudungan, Desa Bontihing, Kecamatan Kubutambahan, Kabupaten Buleleng dilihat dari hasil analisis perbandingan pendapatan maka didapat hasil pendapatan bersih usahatani cabai rawit dengan menggunakan pupuk anorganik sebesar Rp 21.553.513,00 dan usahatani cabai rawit dengan menggunakan pupuk campuran sebesar Rp 26.456.458,00. Adapun hasil perbandingan pendapatan usahatani cabai rawit dengan menggunakan pupuk anorganik dan pupuk campuran diketahui tidak berbeda nyata. Hasil analisis tersebut didasari perhitungan menggunakan Uji-t.

\subsection{Saran}

Berdasarkan hasil penelitian yang telah diperoleh, maka saran yang dapat diberikan sebagai berikut.

1. Saran yang diberikan dari hasil penelitian yang telah dilakukan dengan didapatkannya hasil tidak berbeda nyata antara perbandingan pendapatan bersih usahatani cabai rawit dengan menggunakan pupuk anorganik dan pupuk campuran, diharapkan petani dapat menerapkan penggunaan pupuk campuran. 
Adapun hal tersebut didasari bahwa pendapatan bersih usahatani cabai rawit dengan menggunakan pupuk campuran lebih tinggi dibandingkan dengan usahatani cabai rawit dengan menggunakan pupuk anorganik dengan hasil perbandingan tidak signifikan, dan faktor lain bahwa penggunaan pupuk campuran (organik dan anorganik) dapat mengurangi pencemaran lingkungan dikarenakan penggunaan pupuk anorganik yang berkepanjangan dan terlalu banyak membuat lingkungan menjadi tercemar.

2. Diharapkan bagi pemerintah dapat terus memberikan inovasi baru terhadap budidaya usahatani cabai rawit di Subak Kudungan dalam mencapai swasembada cabai rawit di Bali, agar terwujudnya usahatani cabai rawit yang berkelanjutan.

\section{Ucapan Terima Kasih}

Penulis mengucapkan banyak terimakasih kepada semua pihak yang telah membantu dalam pelaksanaan penelitian ini, terutama kepada Pekaseh dan seluruh responden di Subak Kudungan serta kedua orang tua yang telah memberikan bantuan baik moril maupun materil dalam penyusunan e-jurnal ini sehingga dapat selesai tepat pada waktunya.

\section{Daftar Pustaka}

Antara, M dkk. 2006. Bahan Ajar Metodelogi Penelitian Agribisnis. Program Magister Agribisnis Program Sarjana Universitas Udayana, Denpasar.

BPS. 2015. Survei Pertanian. Produksi Tanaman Sayuran dan Buah-buahan di Indonesia. Biro Pusat Statiskik. Jakarta.

Cahyono B. 2003. Cabai Rawit; Teknik Budidaya dan Analisis Usaha Tani. Yogyakarta: Kanisius.

Direktur Jendral Bina Produksi Hortikultura. 2015. Statistik Hortikultura Tahun 2014. Dirjen Hortikultura, Departemen Pertanian, Jakarta 125 hal.

Hadisapoetra, S. 1979. Biaya dan Pendapatan dalam Usahatani. Yogyakarta: Departemen Ekonomi Pertanian Universitas Gajah Mada.

Hakim, A. 2004. Statistik Deskriptif untuk Ekonomi dan Bisnis. Jakarta: Ekonesia.

Okas, Gede. 2014. Laporan Penyelenggaraan Pemerintahan Desa (LPPD) Desa Songan B Tahun Anggaran 2014.

Rahim, A.dan Diah R.D.H. 2008. Pengantar, Teori, dan Kasus Ekonomika Pertanian. Cetakan Kedua. Jakarta: Penebar Swadaya.

Setiawati, W. 2010. Modul Pelatihan SL-PTT Cabai Merah-Bawang Merah. Pusat Penelitian dan Pengembangan Hortikultura, Badan Penelitian dan Pengembangan Pertanian, Kementerian Pertanian.

Soekartawi, dkk. 1986. Ilmu Usahatani dan Penelitian Untuk Pengembangan Petani Kecil. Penerbit Universitas Indonesia, Jakarta. 